\title{
Pigment specific in vivo light absorption of phytoplankton from estuarine, coastal and oceanic waters
}

\author{
P. A. Stæhr ${ }^{1,2, *}$, S. Markager ${ }^{1}$, K. Sand-Jensen ${ }^{2}$ \\ ${ }^{1}$ National Environmental Research Institute, Department of Marine Ecology, Frederiksborgvej 399, Box 358, \\ 4000 Roskilde, Denmark \\ ${ }^{2}$ Freshwater Biological Laboratory, University of Copenhagen, Helsingørgade 51, 3400 Hillerød, Denmark
}

\begin{abstract}
The influence of phytoplankton photoacclimation and adaptation to natural growth conditions on the chlorophyll $a$-specific in vivo absorption coefficient $\left(a^{*} \mathrm{ph}\right)$ was evaluated for samples collected in estuarine, coastal and oceanic waters. Despite an overall gradient in the physio-chemical environment from estuaries, over coastal, to oceanic waters, no clear relationships were found between $a^{*}{ }_{\mathrm{ph}}$ and the prevailing light, temperature, salinity and nutrient concentrations, indicating that short-term cellular acclimation was of minor importance for the observed variability in $a^{*}$ ph. The clear decline in $a^{*}$ ph from oceanic, over coastal, to estuarine waters was, however, strongly correlated with an increase in cell size and intracellular chlorophyll a ( $\mathrm{chl}$ a) content of the phytoplankton, and a reduction of photosynthetic carotenoids relative to chl $a$. Variations in photoprotective carotenoids relative to chl $a$ seemed to be of minor importance for the variability in $a^{*}{ }_{\mathrm{ph}}$. In addition, significant differences in phytoplankton composition and abundance were observed, primarily driven by an increase in the abundance of diatoms, which furthermore correlated with increasing pigment packaging and decreasing $a^{*}$ ph. The observed differences in $a^{*}$ ph were, therefore, primarily driven by longerterm adaptations of the phytoplankton community. Our data suggests that an overall increase in nutrient loading from oceanic to estuarine waters increases phytoplankton abundance and favors larger sized species, particularly within the diatoms. These changes eventually decrease $a^{*} \mathrm{ph}$ through a rise in the package effect and a lower abundance of photosynthetic carotenoids relative to chl $a$.
\end{abstract}

KEY WORDS: Phytoplankton · Light absorption · Photoacclimation · Adaptation · Pigmentation · Community structure $\cdot$ Cell size

Resale or republication not permitted without written consent of the publisher

\section{INTRODUCTION}

In vivo light absorption by phytoplankton pigments is a key parameter in bio-optical models for growth and productivity of phytoplankton in the sea (Plat \& Sathyendranath 1988, Morel \& André 1991, Platt et al. 1995, Sathyendranath et al. 1995). The absorbing properties of phytoplankton pigments also constitute an important component in models estimating algal biomass ( $\mathrm{chl}$ a) from measurements of water-leaving radiance (Gordon \& Morel 1983). The chl a-specific absorption coefficient $\left(a^{*}{ }^{*}\right)$ is an essential parameter in both cases because it constitutes the link between phytoplankton biomass and light absorption by phytoplankton.

Significant variability in $a^{*}$ ph has been found over regional scales (Hoepffner \& Sathyendranath 1992, Bricaud et al. 1995, Cleveland 1995, Lutz et al. 1996, Allali et al. 1997, Ciotte et al. 1999, 2002) and between seasons (Sathyendranath et al. 1999). This variability has been explained by differences in pigment packaging (e.g. Morel \& Bricaud 1981, Sathyendranath et al. 1987, Mitchell \& Kiefer 1988) and pigment composition (e.g. Bricaud et al. 1983, Sathyendranath et al. 1987, 
Berner \& Dubinsky 1989). Pigment packaging and composition exhibit both inter- and intraspecies differences. Whereas the interspecific variability in cellular pigmentation and, thereby, in $a^{*}$ ph stems from overall differences in taxonomy, cell size and cell morphology, the intraspecific variability stems from acclimation of the algal cells to prevailing light, temperature and nutrient levels. Therefore, we can expect $a^{*}{ }_{\mathrm{ph}}$ of a natural phytoplankton sample to vary significantly over time and space due to either short-term acclimation to the prevailing growth conditions and/or longer-term adaptation in the composition of the phytoplankton community.

Acclimation of the algal cells to growth conditions is a dynamic process occurring at different time scales. Acclimation occurring at a morphological and cellular level happens over the time scale of a cell generation corresponding to between 1 and a few days, depending on species and growth conditions. This type of acclimation, called photoacclimation, includes changes in cell volume, pigment composition and concentration, and number and density of thylakoid membranes (Falkowski \& LaRoche 1991). Significant changes in these parameters together with $a^{*}$ ph have been found over such a time scale (e.g. Sathyendranath et al. 1987, Mitchell \& Kiefer 1988, Berner \& Dubinsky 1989, Sosik \& Mitchell 1991, Stæhr et al. 2002, Stæhr \& Cullen 2003). Furthermore, acclimation may occur at a physiological level within the course of a cell generation, generating significant variations in pigmentation and $a^{*}{ }_{\mathrm{ph}}$ within a light:dark cycle (Ohi et al. 2002). Finally, acclimation may happen extremely fast. Pigments are embedded in proteins that undergo structural changes through photophosphorylation when exposed to changes in irradiance. This may happen within minutes or even seconds, affecting the absorption efficiency of the photosystem (Falkowski \& Raven 1997) which eventually alters the in vivo biooptical characteristics of a phytoplankton species (Johnsen et al. 1997).

Phytoplankton constantly acclimates to the prevailing growth conditions at different time scales. What is presently not so well known is how these factors interplay with longer-term adaptation of the community composition in determining the light absorbing properties of phytoplankton living in the sea. Experimental work with different marine species of phytoplankton suggests that photoacclimation to the prevailing growth conditions is less important for $a^{*}$ ph variation than interspecific differences in pigment packaging and composition (Stæhr et al. 2002, Fujiki \& Taguchi 2002). This study aims to describe the overall pattern in in vivo light absorption characteristics of phytoplankton in estuarine, coastal and oceanic waters. Specifically, we evaluate the importance of phytoplankton photoacclimation and adaptation for the shape and overall level of $a^{*}{ }_{\mathrm{ph}}$ spectra.

\section{MATERIALS AND METHODS}

Study area. Measurements of phytoplankton light absorption, phytoplankton pigmentation, phytoplankton size, availability of nutrients and irradiance in the water column were carried out in 3 different water types: Danish estuaries, Danish coastal waters and the Greenland Sea (see Table 1 \& Fig. 2). The studied Danish estuaries are generally shallow (mean depth: 5 to $10 \mathrm{~m}$ ) and receive high annual nutrient inputs ( 24 to $33 \mathrm{~g}$ total $\mathrm{N} \mathrm{m}^{-2}$; Hansen et al. 2000). The estuaries have frequent blooms of large diatoms and relatively brief periods of nutrient limitation during summer (Hansen et al. 2000). The studied Danish coastal waters included the Sound, the Belt Sea, Kattegat, Skagerrak and the SE North Sea. These areas have deeper waters (mean depth: 15 to $20 \mathrm{~m}$ ), lower annual nutrient loading ( $c a$. 3 to $8 \mathrm{~g}$ total $\mathrm{N} \mathrm{m}^{-2}$; Rasmussen \& Gustafsson 2003) and smaller and less frequent blooms of phytoplankton than the estuaries (Hansen et al. 2000). The Greenland Sea is a deep oceanic area of relatively low annual nutrient loading (ca. $4.5 \mathrm{~g}$ total $\mathrm{N} \mathrm{m}^{-2}$ ) and has phytoplankton communities dominated by small species. The annual nutrient loading into the Greenland Sea was estimated from measurements of annual new production (ca. $27 \mathrm{~g} \mathrm{C} \mathrm{m}^{-2}$; Bodungen et al. 1995) and an assumed $C: N$ ratio of 6 . In the Sound and the Greenland Sea, samples were taken at the surface (2 to $5 \mathrm{~m}$ ) and in deeper layers at the chl a maximum. At all other locations, samples were only taken at the surface $(1 \mathrm{~m})$.

Nutrients, temperature and salinity. Sampling and measurements of nitrite and nitrate $\left(\mathrm{NO}_{2}+\mathrm{NO}_{3}\right)$, phosphorous $\left(\mathrm{PO}_{4}\right)$ and silica $\left(\mathrm{SiO}_{4}\right)$ were performed according to guidelines for the Danish national monitoring programme on the marine environment (Kaas \& Markager 1998). At some of the sampling stations for optical measurements nutrients were not determined. To obtain information for these stations, data from neighboring stations were included, which were part of the Danish national monitoring program and sometimes visited a few days before or after the sampling of the optical parameters. Temperature and salinity data were obtained in all cases from CTD profiles at the sampling time.

Irradiance level. In order to evaluate the importance of growth irradiance, we calculated the mean irradiance level experienced by the plankton community $\left(E_{\text {mean }}\right)$ for all samples collected in the surface waters according to Riley (1957): 


$$
E_{\text {mean }}=E_{0}\left(1-\mathrm{e}^{-K_{d} z}\right) /\left(K_{d} z\right)
$$

where $E_{0}$ is the incident light, $K_{d}$ is the vertical attenuation coefficient and $z$ is the mixing depth of the water column estimated from salinity and temperature profiles. $E_{0}$ was calculated as the daily mean on the day of sampling.

$E_{0}$ was measured for the Greenland Sea samples using a LI-190SA Quantum Sensor located on the ship (RV 'Dana'), and obtained from the Royal Veterinary and Agricultural University of Denmark (Jensen 2000) for all other samples. For most samples, $K_{d}$ was calculated as the slope of a linear regression of $\ln \left(E_{z} / E_{0}\right)$ vs depth, for which $E_{z}$ (irradiance at depth $z$ ) was measured by a spherical quantum sensor (Biospherical QSP200L Log Quantum Scalar irradiance sensor) mounted on the CTD system. However, for some sampling stations, $K_{d}$ was estimated from measurements of Secchi depth $\left(z_{\mathrm{S}}\right)$. In these calculations, we applied the empirically established relationship for Danish waters under overcast situations (Højerslev 1977): $K_{d}=z_{\mathrm{S}} / 2.3$. For samples collected at the depth of maximum fluorescence in the water column, $E_{\text {mean }}$ was calculated according to Lambert-Beers law $\left(E_{z}=E_{0} \mathrm{e}^{-K_{d}}\right)$, where $z$ is the sampling depth.

Cell size. Measurements of phytoplankton cell dimensions and numbers were determined on lugol preserved samples using an inverted microscope, according to the technical guidelines for phytoplankton counts (Kaas \& Markager 1998). According to this guideline, the uncertainty associated with cell counts generally decreases with increasing number of cells counted per taxa. Thus, the level of uncertainty lies between \pm 100 to $\pm 3 \%$ (95\% confidence limit) for samples where 5 to 4000 cell counts were made. Generally, no less than 50 cells were counted per taxa, thus representing a maximum uncertainty of $25 \%$. For each taxa, measurements of cell dimensions were performed on 10 individuals. These measurements were converted into biovolume $\left(B V_{\text {cell }}, \mathrm{m}^{3}\right.$ cell $\left.{ }^{-1}\right)$ using the appropriate allometric conversions (Hillebrand et al. 1999). Multiplying $B V_{\text {cell }}$ by the number of cells of each species and finally summing the biovolume of all species permitted calculation of the total biovolume $\left(B V_{\text {tot }}\right)$. Average cell volume $B V_{\text {Avg }}\left(\mathrm{m}^{3}\right.$ cell $\left.^{-1}\right)$ was determined as total biovolume divided by total number of cells. Assuming cells are spherical, the average Equivalent Spherical Diameter (ESD, $\mu \mathrm{m}$ ) of each water sample was calculated:

$$
E S D=2 \times\left(\frac{3 \times B V_{A v g}}{4 \times \pi}\right)^{\frac{1}{3}}
$$

Pigment analysis. Water samples were gently filtered onto $25 \mathrm{~mm}$ Advantec GF 75 glass fibre filters and immediately stored in liquid nitrogen. Filters were subsequently transferred to $3 \mathrm{ml}$ acetone, sonicated on ice for $15 \mathrm{~min}$, and left to extract for $24 \mathrm{~h}$ at $4^{\circ} \mathrm{C}$ prior to filtering $(0.2 \mu \mathrm{m})$ into HPLC vials containing $1 \mathrm{ml}$ water. HPLC analyses were performed on a Shimadzu LC 10A system with a Supercosil C18 column $(250 \times$ $4.6 \mathrm{~mm}, 5 \mu \mathrm{m}$ ) using a slight modification of the methodology of Wright et al. (1991), as described in Schlüter \& Havskum (1997). Pigments were identified by reten-tion times and absorption spectra identical to those of authentic standards, and quantified against standards purchased from the International Agency for ${ }^{14} \mathrm{C}$ Determination, Hørsholm, Denmark. Accuracy varied from 6 to $11 \%$ (Coefficient of Variance, CV) for the individual pigments, with an average accuracy of $8 \%$ (CV) for all identified pigments. Chlorophyllide a was present in 26 of the estuarine samples. These samples were dominated by diatoms which contain chlorophyllase that rapidly converts chl $a$ to chlorophyllide $a$ if cellular organelles are disrupted during filtration of samples (Jeffrey \& Hallegraeff 1987). Since chlorophyllide $a$ has an absorption signature almost identical to chlorophyll $a$, the sum of chlorophyllide $a$ and chlorophyll a was chosen to represent chlorophyll a. The applied method does not provide a full baseline separation of zeaxanthin and lutein. These pigments were therefore manually identified from absorption spectra and correct integration of peak areas confirmed through inspection of chromatograms. Accuracy of zeaxanthin and lutein measurements were 9 and $11 \%(\mathrm{CV})$ respectively.

Phytoplankton community structure. Abundance of phytoplankton classes was estimated from measurements of chlorophyll and carotenoid pigments using the CHEMTAX program (Mackey et al. 1996). Pigment ratio files, obtained from laboratory experiments with species representative of the collected samples (Henriksen et al. 2002), were applied in order to calculate the relative abundance of the different phytoplankton classes. According to Mackey et al. (1996), the accuracy of CHEMTAX calculations are optimized when calculations are done on smaller groups of samples where one can expect a higher degree of similarity in the species composition. We therefore divided the data set into subsets derived from similar environments with respect to irradiance, nutrients and temperature. This procedure resulted in the following 5 groups: (1) the Greenland Sea (oceanic waters); (2) Aarhus Bight and Danish open waters (coastal waters); (3) Esbjerg (coastal waters); (4) the Sound (coastal waters) and (5) Horsens Fjord and Mariager Fjord (estuaries). Although samples from coastal waters were split into sub areas prior to CHEMTAX calculations, we still consider coastal samples to differ noticeably in taxonomic composition from oceanic and estuarine samples. Table 1 provides a characterisation of the samples. 
Phytoplankton absorption. Spectral absorption (400 to $800 \mathrm{~nm}$ by $0.5 \mathrm{~nm}$ ) of particulate material was determined using the quantitative filtering technique described by Kishino et al. (1985), using a Shimadzu UV-2401PC UV-Vis recording spectrophotometer equipped with an integrating sphere type ISR-240A and placing the sample at a port outside the sphere. Samples were either measured immediately or preserved in liquid nitrogen for a maximum of 2 mo until analysis. Assessment of the preservation method showed that the optical densities of a phytoplankton sample was slightly reduced $(<3 \%)$ immediately after preservation. However, longer preservation (21 d) caused no significant change in the optical density. Optical density spectra were smoothed using a $10 \mathrm{~nm}$ running average, and corrected for background absorption by subtracting the average optical density measured between 750 and $800 \mathrm{~nm}$. The corrected optical densities were converted into absorption coefficients using the $\beta$-correction method given by Arbones et al. (1996):

$$
\beta(\lambda)=1 / 0.37+0.42 \times \mathrm{OD}(\lambda)
$$

where OD is the optical density of the particulate material measured on a filter pad and $\lambda$ is the wavelength. The particulate absorption coefficients were then calculated as:

$$
a_{p}(\lambda)=2.3 \times \mathrm{OD}(\lambda) \times \mathrm{AF} / V \times[1.63 \times \mathrm{OD}(\lambda) \times \beta(\lambda)]
$$

where $V$ is the filter volume and $\mathrm{AF}$ the effective filter area. The $\beta$-correction method given by Arbones et al. (1996) was chosen as it has been found to provide the most accurate absorption estimates, compared with other frequently used $\beta$-correction methods (Finkel \& Irwin 2001). The spectral absorption by detritus $\left[a_{\text {det }}(\lambda)\right]$, was corrected for by measuring the absorption before and after methanol extraction, according to the procedure described by Kishino et al. (1985), in order to derive absorption by phytoplankton $\left[a_{\mathrm{ph}}(\lambda)\right]$ :

$$
a_{\text {ph }}(\lambda)=a_{p}(\lambda)-a_{\text {det }}(\lambda)
$$

$a_{\text {det }}(\lambda)$ was, however, not measured for all samples. We therefore decided to use the numerical method developed by Bricaud \& Stramski (1990) to mathematically partition the phytoplanktonic and detrital absorption for all samples. The numerical method was compared with the extraction method of Kishino et al. (1985) on 106 samples (Fig. 1). Linear regression showed that the offset of the regression line was not significantly different from zero $(p=0.26)$. Further, the identity line fell within the $95 \%$ confidence limits, indicating that the slope was not significantly different from 1 . On these grounds, we conclude that the applied numerical method of Bricaud \& Stramski (1990) produced reliable estimates of the detritus absorption, allowing the use of

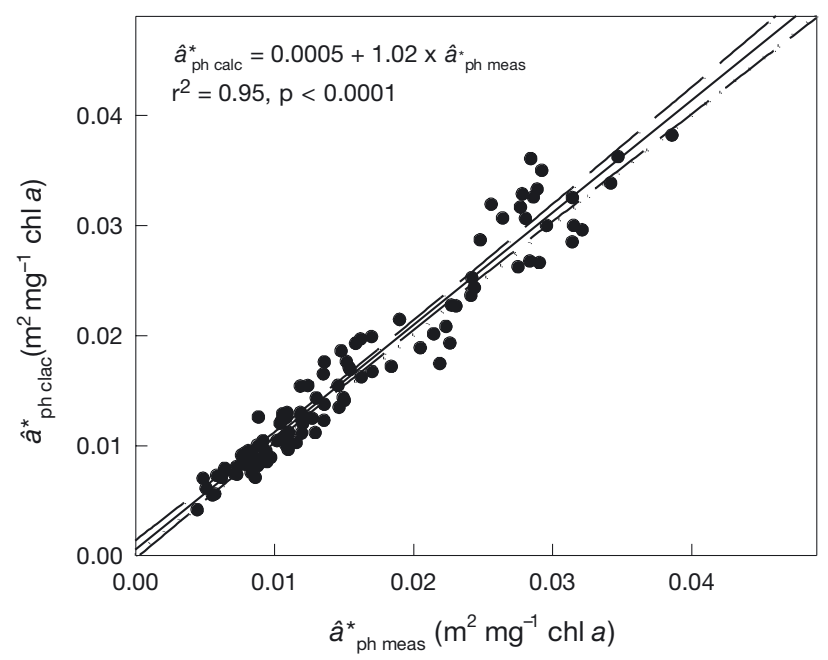

Fig. 1. Relationship between calculated $\left(\hat{a}^{*}\right.$ ph calc $)$ (Bricaud \& Stramski 1990) and measured ( $\hat{a}^{*}$ phmeas) (Kishino et al. 1985) values of the mean spectral chl a-specific absorption coefficient, $\hat{a}^{*}{ }_{\mathrm{ph}}$. Full line represents the regression line and dotted lines represent $95 \%$ confidence limits. $\mathrm{N}=106$

spectra in which only the particulate absorption was measured.

Absorption spectra were studied per unit concentration of $\left[\begin{array}{lll}\mathrm{chl} & \mathrm{a}\end{array}\right]$ and per unit concentration of total pigment content $\left(\mathrm{T}_{\mathrm{pig}}=\right.$ sum of all HPLC measured pigments). Chl $a$-specific absorption was calculated according to:

$$
\begin{aligned}
& a^{*}{ }_{p h}(\lambda)\left(\mathrm{m}^{2} \mathrm{mg}^{-1} \operatorname{chl} a\right)= \\
& a_{\mathrm{ph}}(\lambda)\left(\mathrm{m}^{-1}\right) / \operatorname{chl} a\left(\mathrm{mg} a \mathrm{~m}^{-3}\right)
\end{aligned}
$$

The mean spectral (400 to $700 \mathrm{~nm}) \mathrm{chl}$ a-specific absorption coefficient was used to characterize the overall phytoplankton absorption:

$$
\hat{a}_{\mathrm{ph}}^{*}=\frac{\sum_{400}^{700} a^{*}{ }_{\mathrm{ph}}(\lambda)}{\mathrm{n}}
$$

where $n$ is the number of wavelengths $(n=601)$. The measure $\hat{a}^{*}$ ph has previously proven valuable in determining differences in phytoplankton absorption as it reflects changes in both flatness and shape of the absorption spectra (Markager \& Vincent 2001, Stæhr et al. 2002). By replacing chl $a$ with the sum of all pigments $\left(\mathrm{mg} \mathrm{T}_{\text {pig }} \mathrm{m}^{-3}\right)$ in Eq. $6, a_{\text {Tpig }}^{*}(\lambda)$ was calculated.

Statistics. Correlations between environmental growth conditions (light, nutrients, temperature and salinity) and pigmentation, absorption, cell size and taxonomic composition of the phytoplankton were analyzed by Spearman rank correlation analysis. This non-parametric method was chosen since environmental data did not conform to the requirements of parametric tests, and further contained a high degree of inter-correlation for most variables. 
Differences in phytoplankton community structure between the water systems were analyzed using nonparametric multivariate statistical analysis according to the guidelines provided by Clarke (1993). Nonparametric multi-dimensional scaling (nMDS) was used to illustrate the distance (i.e. dissimilarity) between community samples, based on the Bray-Curtis similarity measure. One-way analysis of similarity (ANOSIM; Clarke \& Warwick 1994) was subsequently used to test whether the community structure differed significantly between water systems. The multivariate analysis were performed using the PC software PRIMER (Plymouth Marine Laboratories) on double square-root transformed data on phytoplankton class abundance, obtained by the CHEMTAX calculations.

To determine whether average values of $\hat{a}^{*}{ }_{p h}$ were significantly different depending on water type (estuarine, coastal and oceanic), sampling season (spring, summer, fall and winter) and sampling depth (surface and deep chlorophyll maximum), we applied factorial ANOVA (SAS GLM procedure; SAS Institute Inc.). Similarly, we applied factorial ANOVA to test the effect of irradiance $\left(E_{\text {meani }} 25,75,150,300\right.$ and $600 \mu \mathrm{mol}$ photons $\left.\mathrm{m}^{-2} \mathrm{~s}^{-1}\right)$, nutrient availability $\left(\mathrm{NO}_{2}+\right.$ $\mathrm{NO}_{3} ; 1,4,9,18$ and $\left.36 \mu \mathrm{M}\right)$ and temperature $(2,7,12$, 17 and $22^{\circ} \mathrm{C}$ ). In order to perform this analysis, we determined 5 numerical levels for each environmental variable. Frequency distributions were used to find the levels representing the original data range. The original values of $E_{\text {mean, }} \mathrm{NO}_{2}+\mathrm{NO}_{3}$ and temperature were subsequently replaced with the level lying closest to the original value.

\section{RESULTS}

\section{Environmental conditions and phytoplankton composition}

Samples were grouped according to the site of collection in estuarine, coastal or oceanic waters (Table 1). The division into 3 crude water types was supported by the measurements shown in Fig. 2. Estuarine waters had low salinities, high temperatures and higher levels of irradiance and nutrients, resulting in a high phytoplankton biomass of large cells with a high pigment content but a low carotenoid:chl a ratio. Conversely, oceanic waters had high salinities, low temperatures and lower levels of irradiance and nutrients due to a large mixing depth and the long distance from land. As a consequence, oceanic waters had a low phytoplankton biomass of small cells with a low pigment content but a high carotenoid:chl a ratio. Coastal waters had intermediate levels of all of the above-mentioned variables, except for high concentrations of nitrate. The 5 characteristics of the phytoplankton were all significantly intercorrelated and significantly correlated with a decrease in irradiance, water temperature, salinity and silicate (Table 2). The changes in phytoplankton abundance, cell size and pigmentation was also associated with changes in phytoplankton community structure (Fig. 3). The change in community structure was confirmed by the ANOSIM analysis (overall $\mathrm{p}<0.001$; Table 3 ). The main change from oceanic to estuarine waters was an increase in diatoms (large cells; Fig. 4) and a decrease in flagellates, especially prymnesiophytes and prasinophytes (Fig. 5), which are characterized by smaller cells (Fig. 4).

Table 1. Region and sampling period in estuarine (est), coastal (coast) and oceanic (ocean) water types and range of chl $a$ and carotenoid concentrations and mean spectral $(400$ to $700 \mathrm{~nm}) \mathrm{chl} a$-specific absorption $\left(\hat{a}^{*}\right.$ ph $)$. nd $=$ not done

\begin{tabular}{|c|c|c|c|c|c|c|}
\hline Location & $\begin{array}{l}\text { Sampling } \\
\text { period }\end{array}$ & $\begin{array}{l}\text { Water } \\
\text { type }\end{array}$ & $\begin{array}{c}\text { Chl } a \\
\left(\mu \mathrm{g} \mathrm{l}^{-1}\right)\end{array}$ & $\begin{array}{l}\text { Carotenoid } \\
\left(\mu \mathrm{g} \mathrm{l}^{-1}\right)\end{array}$ & $\begin{array}{c}\hat{a}^{*}{ }_{\mathrm{ph}} \\
\left(\mathrm{m}^{2} \mathrm{~g}^{-1} \mathrm{chl} a\right)\end{array}$ & $\mathrm{N}$ \\
\hline Horsens Fjord & Jun 98 & est & $2.15-13.8$ & $1.43-8.66$ & $14.3-39.3$ & 13 \\
\hline Horsens Fjord & Jun 99 & est & $4.20-24.4$ & $2.26-8.13$ & $4.4-19.0$ & 18 \\
\hline Horsens Fjord & Sep 99 & est & $4.84-15.5$ & $4.36-14.1$ & $10.0-20.1$ & 6 \\
\hline Mariager Fjord & Sep 99 & est & $4.26-88.1$ & $3.15-45.9$ & $6.8-26.0$ & 26 \\
\hline Danish open waters & Aug 97 & coast & $0.46-2.37$ & $0.42-2.00$ & $17.6-33.0$ & 20 \\
\hline Danish open waters & Aug 98 & coast & $1.05-9.04$ & $0.75-4.89$ & $7.9-44.2$ & 13 \\
\hline SE North Sea & Jun 98 & coast & $1.97-6.00$ & $2.68-4.82$ & $10.4-23.8$ & 6 \\
\hline SE North Sea & Jun 99 & coast & $6.30-18.6$ & $3.34-9.47$ & $4.5-21.2$ & 11 \\
\hline SE North Sea & Sep 99 & coast & $2.19-9.61$ & $1.72-3.42$ & $12.5-45.9$ & 10 \\
\hline Aarhus Bight & Sep 99 & coast & $1.55-2.87$ & $2.66-4.49$ & $19.5-48.4$ & 5 \\
\hline The Sound (surface) & Mar-Dec 99 & coast & $0.43-7.55$ & $0.15-4.53$ & $11.4-36.8$ & 21 \\
\hline The Sound (chl a max) & Mar-Dec 99 & coast & $0.33-9.72$ & $0.17-7.29$ & $13.3-52.2$ & 19 \\
\hline Danish open waters & Feb 01 & coast & $0.25-1.26$ & nd & $16.0-45.3$ & 24 \\
\hline Greenland Sea (surface) & Aug 99 & ocean & $0.21-1.06$ & $0.18-1.01$ & $20.3-41.7$ & 26 \\
\hline \multirow[t]{2}{*}{ Greenland Sea (chl a max) } & Aug 99 & ocean & $0.21-5.02$ & $0.13-3.09$ & $9.7-51.7$ & 26 \\
\hline & & Total & $0.19-88.1$ & $0.13-45.9$ & $4.4-52.2$ & 244 \\
\hline
\end{tabular}




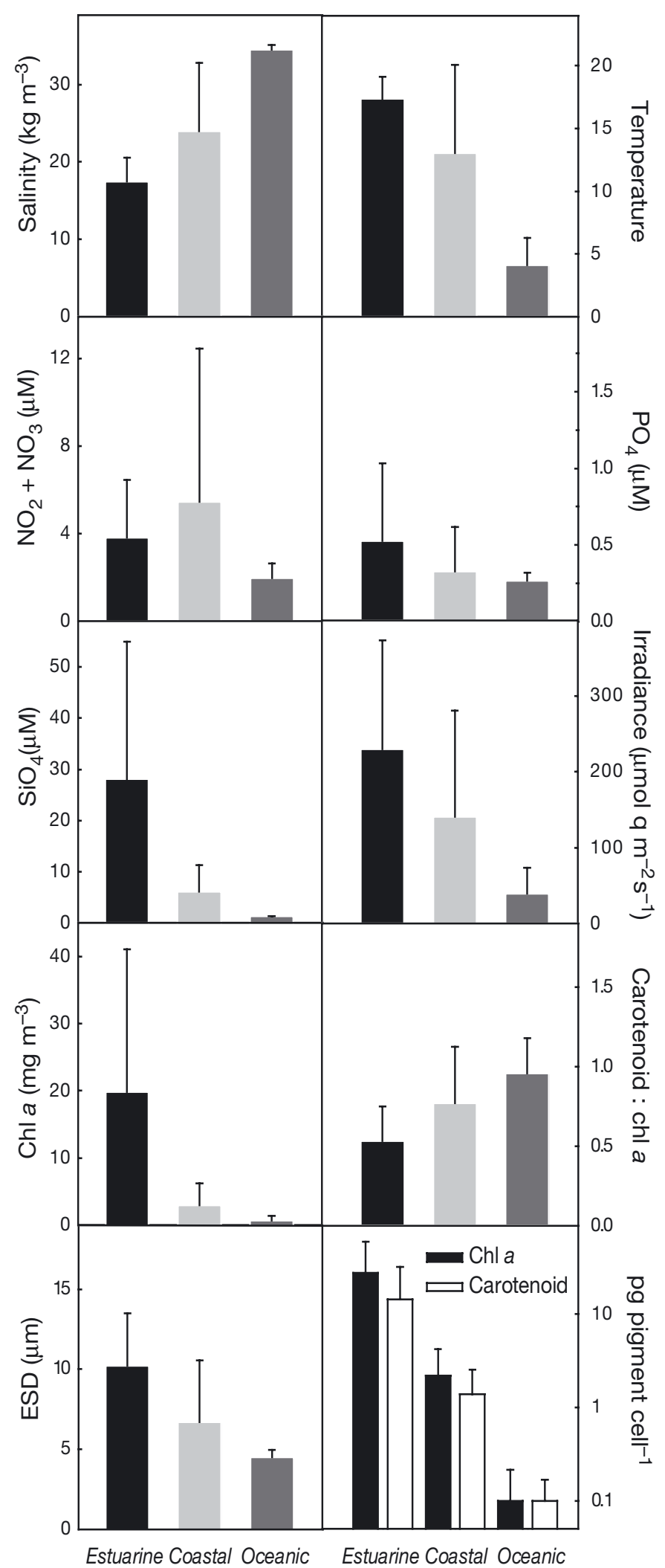

Fig. 2. Mean values (+ 1SD) of environmental variables, phytoplankton abundance, pigmentation and cell size in estuaries, coastal and oceanic waters

\section{Spectral differences in pigment specific absorption coefficients}

Differences were found in the in vivo spectral light absorption of the 3 water types when absorption data was normalised to either $\operatorname{chl} a\left(a^{*}{ }^{*}(\lambda)\right)$ or total pigment $\left(a^{*}\right.$ Tpig $\left.(\lambda)\right)$ (Fig. 6). The similar behaviors of $a^{*}$ ph $(\lambda)$ and $a^{*}$ Tpig $(\lambda)$ was due to a linear relationship between total pigment and chl a concentration (Fig. 7). Regardless of the normalization method, oceanic waters had the highest pigment specific absorption coefficients, followed by coastal waters and estuaries. This rank suggests that the estuaries have higher cell packaging than coastal and oceanic waters. The differences observed in Fig. 6 were tested by performing a 2-way ANOVA on selected wavebands. For this analysis, we chose the wavebands used by the SeaWiFS satellite in the 400 to $700 \mathrm{~nm}$ region $(412,443,490,555$ and $670 \mathrm{~nm}$ ) because these wavebands are particularly important for remote sensing applications. They also represent the main characteristics of a spectrum where $670 \mathrm{~nm}$ is close to the red absorption peak of chl $a_{\text {, }}$ $555 \mathrm{~nm}$ is in the region with minimal influence of pigments, $490 \mathrm{~nm}$ is located at the maximal effects of caroteniods, $443 \mathrm{~nm}$ is approximately at the blue peak of chl $a$ and $412 \mathrm{~nm}$ is in the region where UVprotective pigments can play a role. There was an overall significant difference between water types, irrespective of whether absorption was normalized to [chl a] or [Total pigments] $(\mathrm{p}<0.05)$. The spectral variability, calculated as the coefficient of variability (CV) (Fowler \& Cohen, 1990) of each chl a-specific absorption spectra, was found to be inversely related to cell size $(E S D)$ of the algae $\left(R_{S}=-0.51, p<0.001\right)$. This finding confirmed that the chl a-specific absorption spectra became significantly flatter with increasing cell size of the phytoplankton.

\section{Variability in the spectrally averaged chl a-specific absorption coefficient}

The spectrally averaged chl a-specific absorption coefficient $\left(\hat{a}^{*}{ }_{\mathrm{ph}}\right)$ was inversely related to the product of intracellular chl $a(c i)$ and cell size $(d)$ and positively correlated to the carotenoid : chl a ratio. (Fig. 8 and Table 2). A gradient from oceanic to estuarine samples appeared, further documenting the increasing pigment packaging of the phytoplankton along the gradient. Therefore, phytoplankton from oceanic waters with high $\hat{a}^{*}$ ph coefficients had low pigment packaging and high concentrations of carotenoids relative to chl $a$.

The marked decrease in abundance of diatoms from estuarine to oceanic samples had a significant effect on 
Table 2. Spearman rank correlation coefficients among mean spectral (400 to $700 \mathrm{~nm}) \mathrm{chl} a$-specific absorption $\left(\hat{a}^{*}{ }_{\mathrm{ph}}\right)$, pigmentation ( $\left.\mathrm{chl} a, c i \times d, \mathrm{Caro} / \mathrm{chl} a\right)$, cell size $(E S D)$ and environmental variables $\left(E_{\text {mean }}\right.$ temperature, salinity and nutrients). ns $=$ not significant, ${ }^{*} \mathrm{p}<0.05,{ }^{* *} \mathrm{p}<0.01,{ }^{* * *} \mathrm{p}<0.001$

\begin{tabular}{|c|c|c|c|c|c|}
\hline Variables & $\hat{a}_{\mathrm{ph}}^{*}$ & Chl a & $c i x d$ & Caro/chl a & ESD \\
\hline Chl a & $-0.74^{* * *}$ & & & & \\
\hline$c i \times d$ & $-0.70^{* * *}$ & $0.84^{* * *}$ & & & \\
\hline Caro:chl a & $0.52^{* * *}$ & $-0.64^{* * *}$ & $-0.65^{* * *}$ & & \\
\hline ESD & $-0.26^{* * *}$ & $0.58^{* * *}$ & $0.44^{* * *}$ & $-0.38^{* * *}$ & \\
\hline$E_{\text {mean }}$ & $-0.25^{* * *}$ & $0.42^{* * *}$ & $0.18^{* *}$ & $-0.14^{*}$ & $0.34^{* * *}$ \\
\hline Temperature & $-0.36^{* * *}$ & $0.59^{* * *}$ & $0.39^{* *}$ & $-0.16^{*}$ & $0.64^{* * *}$ \\
\hline Salinity & $0.32^{* * *}$ & $-0.52^{* * *}$ & $-0.53^{* * *}$ & $0.37^{* * *}$ & $-0.55^{* * *}$ \\
\hline $\mathrm{NO}_{2}+\mathrm{NO}_{3}$ & $0.06 \mathrm{~ns}$ & $-0.01 \mathrm{~ns}$ & $0.21^{* *}$ & $-0.29^{* * *}$ & $0.10 \mathrm{~ns}$ \\
\hline $\mathrm{PO}_{4}$ & $0.05 \mathrm{~ns}$ & $-0.09 \mathrm{~ns}$ & $0.11 \mathrm{~ns}$ & $0.03 \mathrm{~ns}$ & $-0.02 \mathrm{~ns}$ \\
\hline $\mathrm{SiO}_{4}$ & $-0.18^{* *}$ & $0.37^{* * *}$ & $0.56^{* * *}$ & $-0.38^{* * *}$ & $0.40^{* * *}$ \\
\hline
\end{tabular}

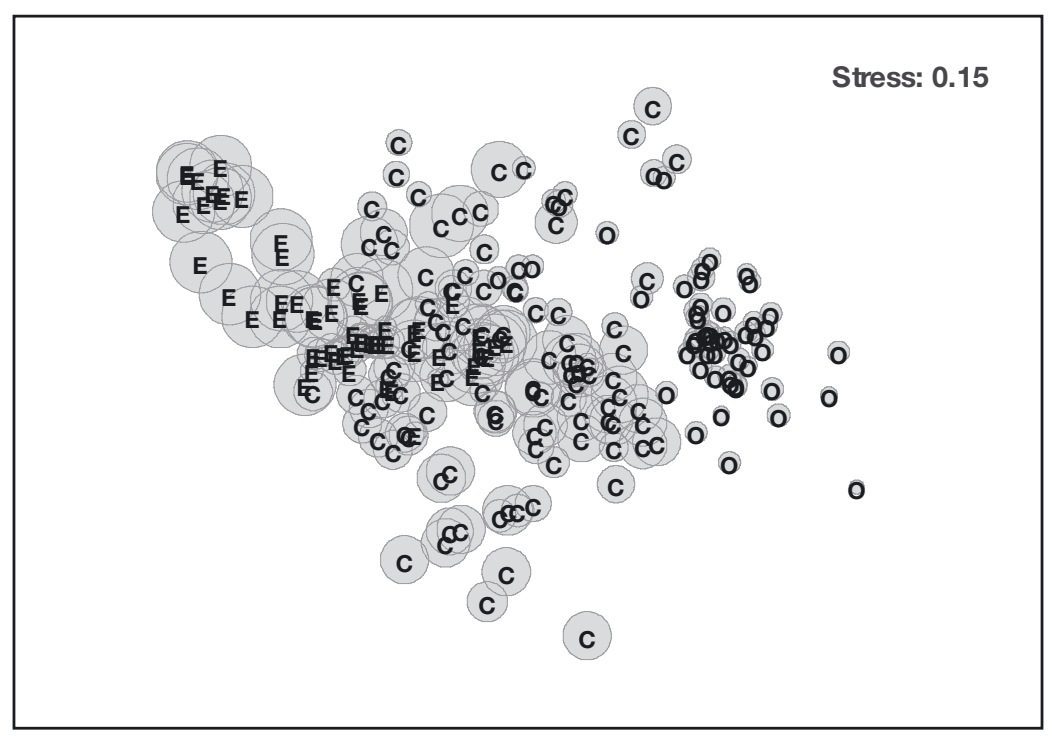

Fig. 3. nMDS (non-parametric multi-dimensional scaling) plot showing the similarity in taxonomic composition between estuarine $(E)$, coastal $(C)$ and oceanic (O) samples $(n=220)$. Determined from Bray-Curtis similarity index and calculated on double square-root transformed abundance data. Circle size reflects the average spherical cell diameter (ranging from 3 to $13 \mu \mathrm{m}$ ) determined for the particular sample

the optical properties of the phytoplankton community. Thus, increasing dominance of diatoms was followed by higher pigment packaging $\left(\mathrm{R}_{\mathrm{S}}=0.53\right.$, $\left.\mathrm{p}<0.001\right)$, lower carotenoid:chl a ratio $\left(\mathrm{R}_{\mathrm{S}}=-0.57, \mathrm{p}<0.001\right)$, and lower $\hat{a}^{*}$ ph values $\left(R_{S}=-0.38, p<0.001\right)$. Increasing dominance of the remaining 8 phytoplankton classes (seen in Fig. 5) were, interestingly, all associated with the opposite effect on pigment packaging, pigment composition and $\hat{a}^{*}$ ph.

A large variability in $\hat{a}^{*}$ ph was found within each water system. The coefficient of variability $(\mathrm{CV})$ was highest in estuarine waters $(\mathrm{CV}=61 \%)$ and lower in coastal $(\mathrm{CV}=$ $41 \%)$ and oceanic waters $(\mathrm{CV}=25 \%)$. Despite the large variability, factorial ANOVA identified significant differences in $\hat{a}^{*}$ ph between estuarine, coastal and oceanic samples (Table 4). However, time of sampling (season) and sampling depth only had a minor influence on the variability in $\hat{a}^{*}{ }_{\mathrm{ph}}$ (Table 4). Overall, weak relationships were found between $\hat{a}^{*}$ ph and the environmental variables included in the analysis. Thus, $\hat{a}^{*}{ }_{\mathrm{ph}}$ tended to decrease with increasing irradiance, temperature and silicate but to increase with higher salinity (Table 2). The weak relationships between $\hat{a}^{*}{ }_{\mathrm{ph}}$ and environmental conditions were also supported by factorial ANOVA, showing that only water temperature had a direct correlation with the level of $\hat{a}^{*}{ }_{\mathrm{ph}}$ (Table 5).

\section{DISCUSSION}

\section{Effect of pigment packaging and composition on the specific absorption coefficient}

In agreement with previous studies (e.g. Morel \& Bricaud 1981, Sathyendranath et al. 1987, Mitchell \& Kiefer 1988), we found pigment specific absorption coefficients to be strongly related to pigment packaging. In this study, pigment packaging was determined as the product of the intracellular chl a concentration ( $c i)$ and the cell diameter $(d)$. The high correlation (Table 2 \& Fig. 8A) between the mean spectral chl a-specific absorption coefficient $\left(\hat{a}^{*}{ }_{\mathrm{ph}}\right)$ and $c i \times d$ was expected, as this correlation has previously been found in experimental studies (Stæhr et al. 2002, Stæhr \& Cullen 2003). Theoretical and experimental studies have shown that randomly oriented ellipsoidal particles behave optically as

Table 3. Probability values of 1-way analysis of similarities (ANOSIM) comparing phytoplankton community structure between estuarine, coastal and oceanic samples. Overall probability $(p)$ was $<0.001$

\begin{tabular}{|lc|}
\hline Water samples & $\mathrm{p}$ \\
\hline Estuarine vs Coastal & $<0.001$ \\
Estuarine vs Oceanic & $<0.001$ \\
Coastal vs Oceanic & $<0.001$ \\
\hline
\end{tabular}




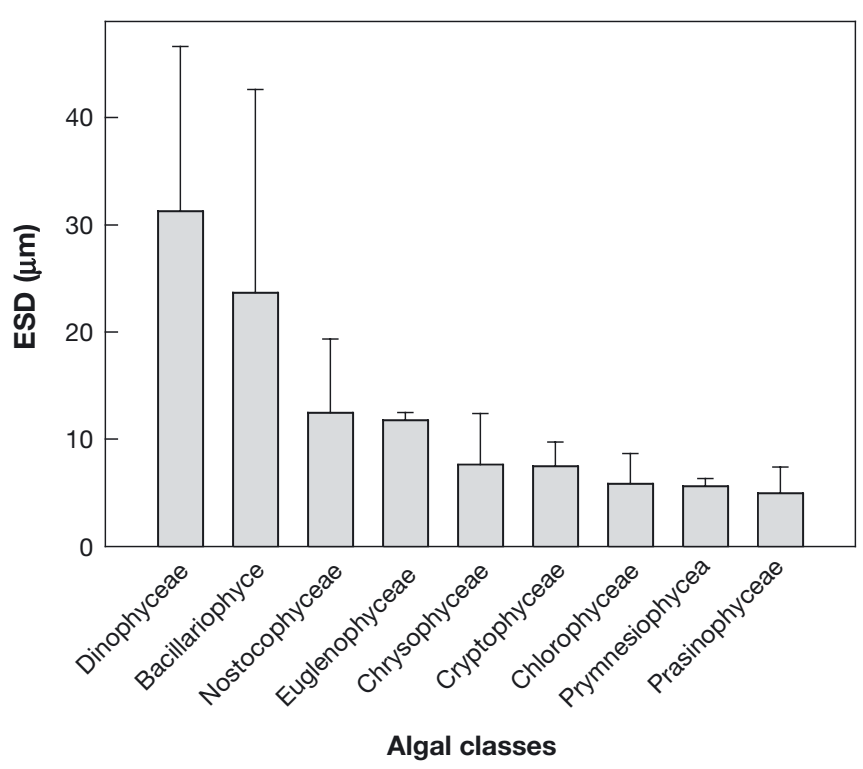

Fig. 4. Size range of phytoplankton classes in Danish waters. Size was determined as the Equivalent Spherical Diameter (ESD) calculated from phytoplankton biovolume measurements using Eq. (2). Data derived from the Danish Monitoring Program under the action plan for the aquatic environment. Only phytoplankton species recorded more than 25 times during the period 1990 to 2000 were included. Error bars represent $1 \mathrm{SD}$

spherical particles of equal volume (Bricaud et al. 1988 and references therein), suggesting that equivalent spherical diameter is a good measure of phytoplankton cell size. Furthermore, the influence of heterogeneity introduced by the presence of chloroplasts, vacuoles or cell walls have been found to be of minor importance for the optical properties of a number of species, which therefore were considered to behave like homoge-

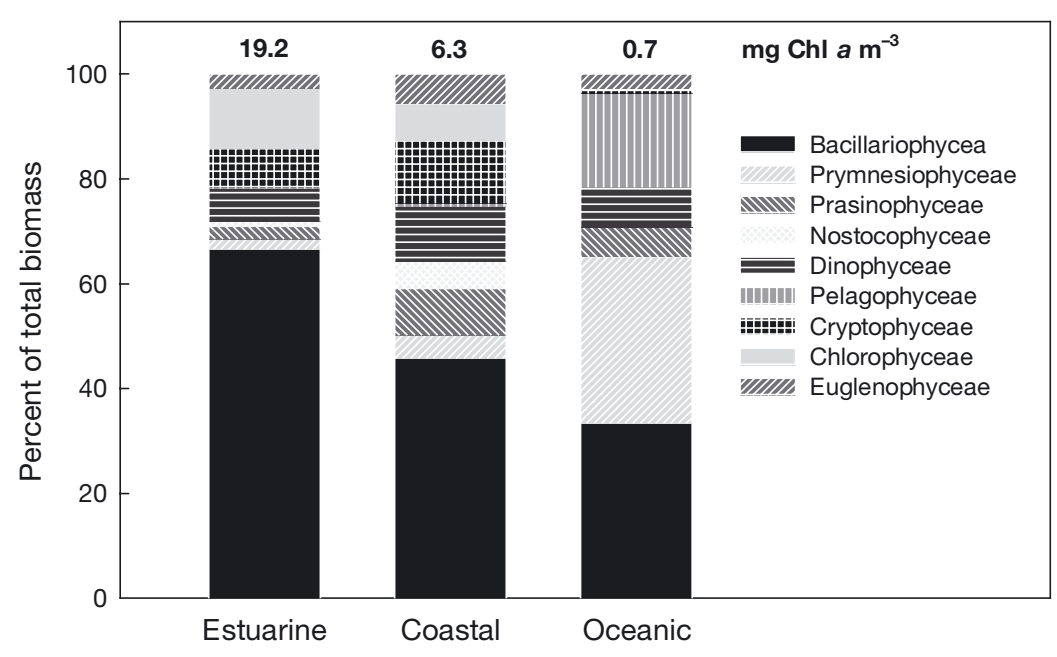

Fig. 5. Relative abundance of phytoplankton classes in estuarine, coastal and oceanic waters neous spheres (Bricaud et al. 1988). On this basis, we find that our calculation of the equivalent spherical size provides a useful measure in the evaluation of optical variations in heterogeneous natural phytoplankton communities. Preservation of phytoplankton samples with lugol fixative may cause cell volume to either decrease or increase. There is, however, no simple way to correct for fixation-induced cell volume changes, as they appear to be highly variable and species-specific (Menden-Deur et al. 2001). This variability, along with a likely underestimation of picoplankton abundance when using microscopic cell counts, will inevitably provide some uncertainty to our estimation of average community cell size. More accurate cell size measurements would undoubtedly strengthen the oberved relationships with light absorption properties.

The linear relationship found between total pigments (accessory pigments $+\mathrm{chl}$ a) and chl a has previously been referred to as a 'community photoadaptive effect' (Trees et al. 2000). According to Trees et al. (2000), this relationship reflects short-term adaptive pigment alterations within single species, or longerterm changes in species composition. In both cases, changing environmental conditions induce changes in pigment composition, which optimize utilization of the available light.

Carotenoid pigments made up 25 to $85 \%$ of the accessory pigments in our samples. Carotenoids absorb strongly in the blue domain and are known to account for much of the variability in the spectral shape of the phytoplankton absorption coefficient (Hoepffner \& Sathyendranath 1991). Bricaud et al. (1995) found that the concentration of carotenoids relative to chl a was consistently higher in oligotrophic than in mesotrophic or eutrophic waters. Our data support this pattern, as we found a significantly higher carotenoid:chl a ratio in the low chlorophyll oceanic waters than in the high chlorophyll estuarine waters (Figs. 2 \& 9A). Increasing amounts of carotenoids raise the overall spectral light absorption, resulting in a higher mean spectral chl $a$-specific absorption coefficient (Fig. 8B). But why do small phytoplankton cells in oligotrophic waters have a consistently higher relative abundance of carotenoids than larger cells in eutrophic waters? The fact that carotenoids contain no nitrogen suggests that these pigments would be favoured in oligotrophic waters. In addition, Bricaud et al. (1995) and Stuart et al. (1998) found that photoprotective carotenoids constitute a larger fraction of the caro- 


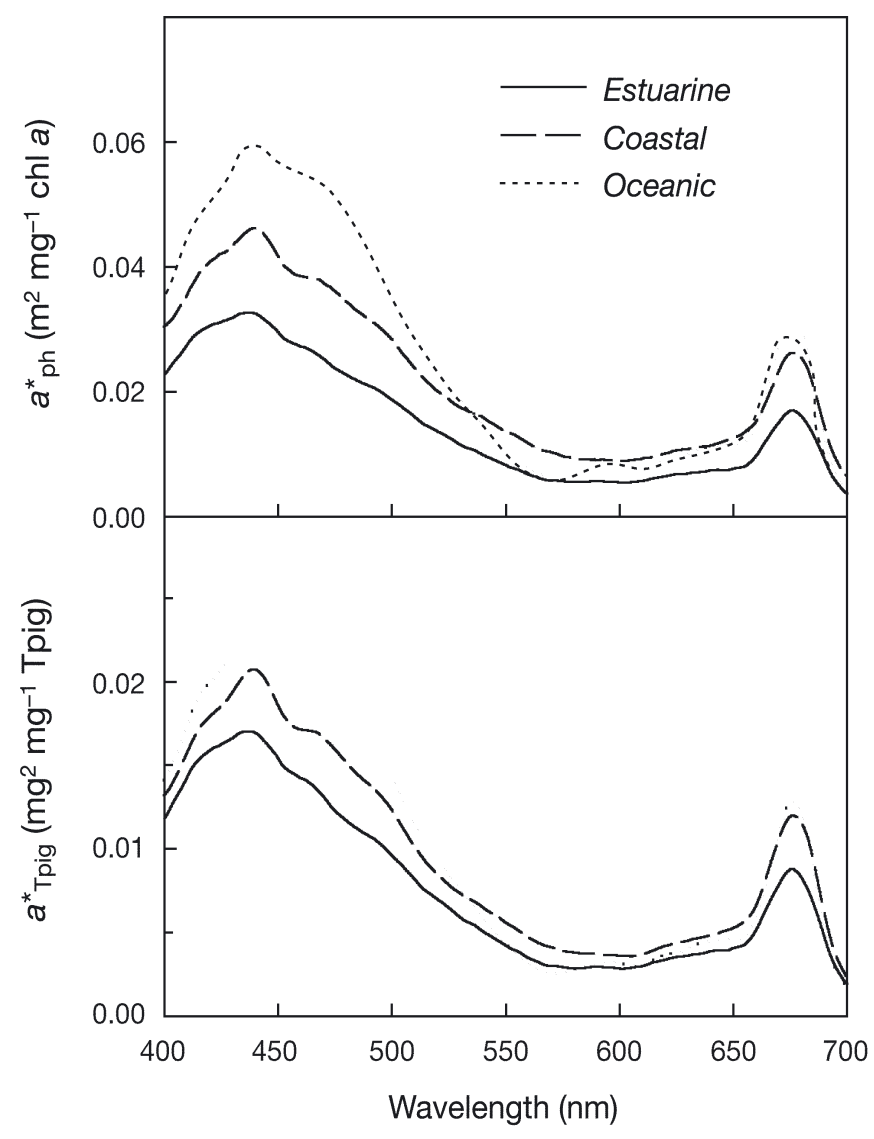

Fig. 6. Chl a-specific $\left(a^{*}{ }_{\mathrm{ph}}\right)$ and total pigment-specific $\left(a^{*}{ }_{\text {Tpig }}\right)$ absorption spectra of estuaries, coastal and oceanic waters. Note the different scales of the y-axes

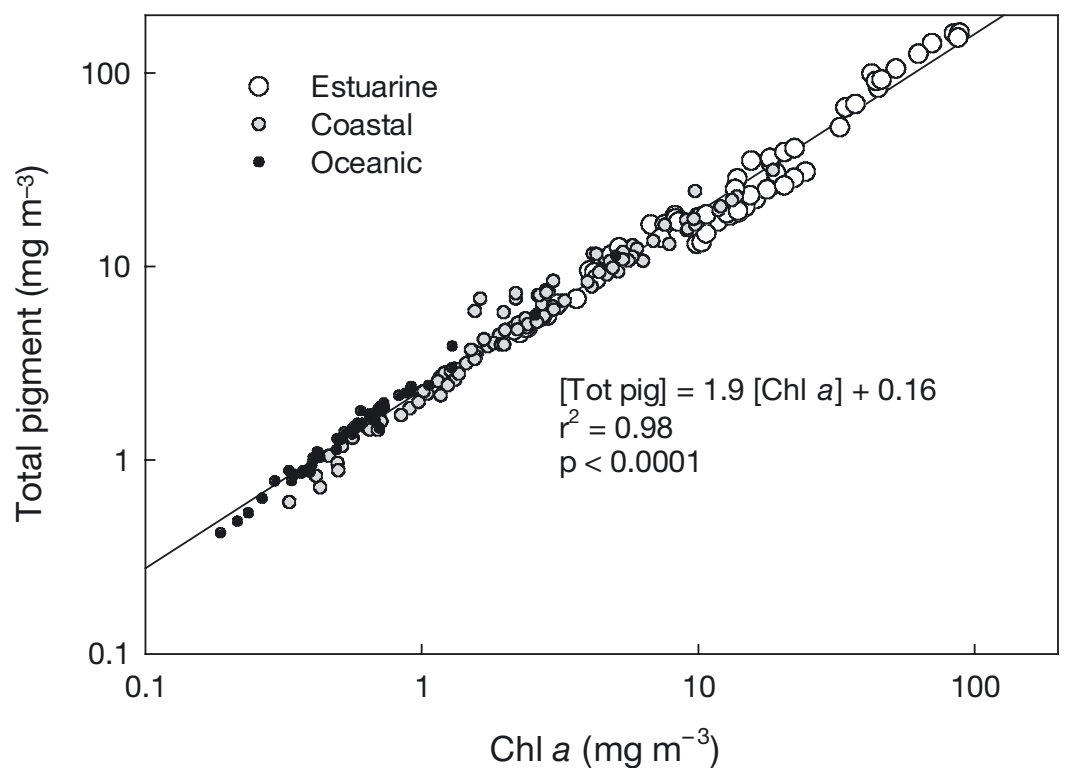

Fig. 7. Relationship between the concentration of all pigments and chl a. Circle sizes indicate the differences in phytoplankton cell size seen in Fig. $2(n=220)$ tenoids in small cells of oligotrophic waters than in large cells of eutrophic waters. A high concentration of photoprotective carotenoids could be advantageous under oceanic conditions with low levels of coloured dissolved organic matter and consequently high exposure to UV-irradiance. Our data only partially supports this argument, however, as we found a relatively small decrease in the relative abundance of photoprotective carotenoids (i.e. zeaxanthin and diadinoxanthin) to chl a with increasing [chl a] (Fig. 9B) and a small difference between water systems $(p=0.10 ; 1$-way ANOVA). Rather, the results suggest that the change in carotenoid composition from estuaries to oceanic water was caused by a decrease in the photosynthetic carotenoids with increasing [chl a] (Fig. 9C), which in turn results in a significant difference between water systems $(\mathrm{p}<0.001 ; 1$-way ANOVA).

\section{Effect of growth conditions on the chl a-specific absorption coefficient}

Under natural conditions, light, temperature and nutrient conditions experienced by the phytoplankton are potentially important sources of variability in $a^{*}{ }_{\mathrm{ph}}$ (Sosik \& Mitchell 1995, Allali et al. 1997). Several experiments have shown that $a^{*}{ }_{\mathrm{ph}}$ can vary significantly as a function of growth irradiance (e.g. Sathyendranath et al. 1987, Mitchell \& Kiefer 1988, Berner \& Dubinsky 1989, Moore et al. 1995, Stæhr et al. 2002) and availability of inorganic nitrogen (Chalup \& Laws 1990; Herzig \& Falkowski 1989; Sosik \& Mitchell 1991, Stæhr et al. 2002). Low irradiance induces biosynthesis of photosynthetic pigments in order to saturate light reactions in the cell. High irradiances, however, induce a decrease in the intracellular chl a concentration, thereby raising the carotenoid:chl a ratio (e.g. Mitchell \& Kiefer 1988, Berner et al. 1989, Sosik \& Mitchell 1991). Acclimation to irradiance is a fast process. Depending on growth condition and species, complete changes may occur within a few days and a significant change in pigmentation may take place after less than $24 \mathrm{~h}$ (Berner \& Dubinsky 1989). $\mathrm{Chl}$ a synthesis is strongly dependent on assimilation of nitrogen. Low availability of nitrogen will therefore cause a decline in cellular chl a content (Stæhr \& Cullen 2003) while high nitrogen availability has been found to increase the cellular chl a concentra- 


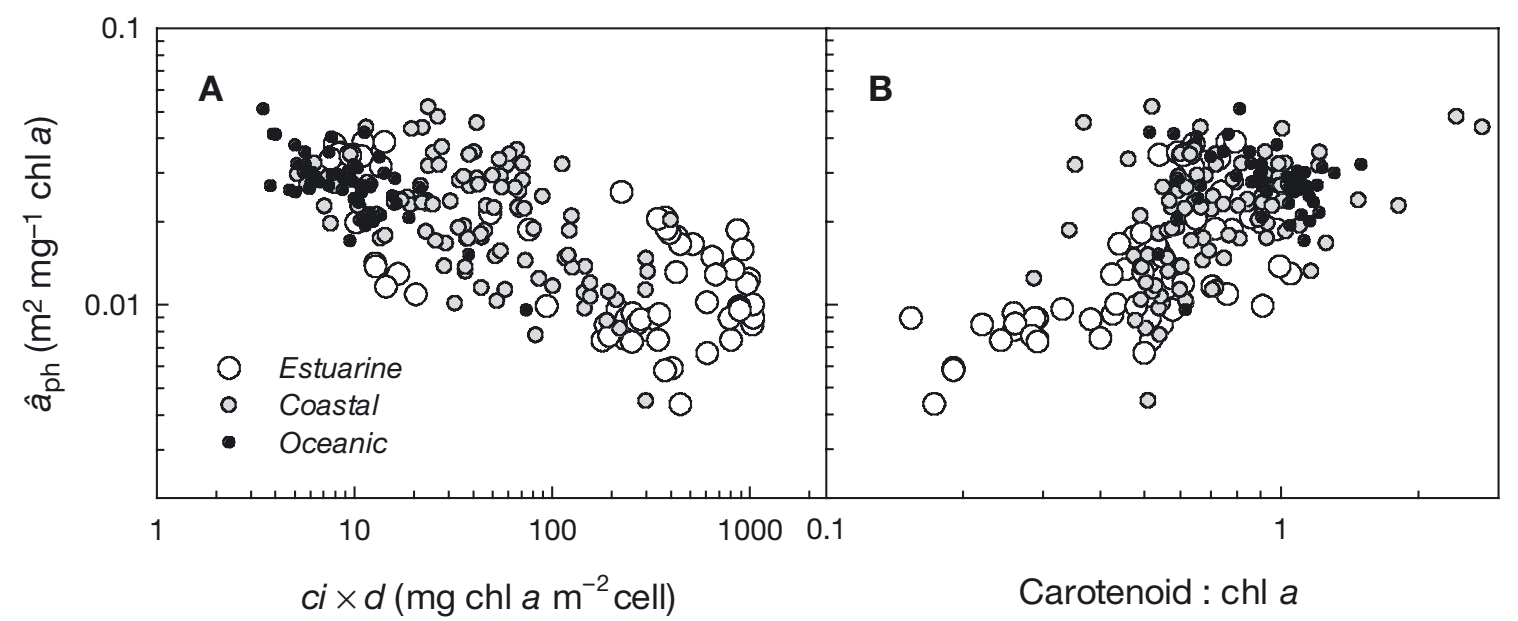

Fig. 8. (A) Mean spectral chl a-specific absorption coefficient $\left(\hat{a}^{*}{ }_{\mathrm{ph}}\right)$ as a function of the product of cell diameter $(d)$ and the intracellular concentration of chl $a(c i)(\mathrm{n}=244)$. (B) $\hat{a}_{\mathrm{ph}}^{*}$ as a function of the carotenoid:chl $a$ ratio. Circle sizes indicate the differences in phytoplankton cell size seen in Fig. 2. $(\mathrm{n}=220)$

tion after a few days, leading to a decrease in $a^{*}$ ph (Sosik \& Mitchell 1991). Sosik \& Mitchell (1995) found that $a^{*}{ }_{\mathrm{ph}}$ of natural phytoplankton in the sea was significantly lower in the nitracline than above it, again confirming the negative relationship between $a^{*}$ ph and nutrient availability.

Surprisingly, irradiance had no effect on the level of $\hat{a}^{*}$ ph (Table 5). If the time scale for photoacclimation is shorter than that for vertical mixing, the expected relationship can be blurred. Mixing depth varied between 1 and $40 \mathrm{~m}$ for the collected samples, with $72 \%$ collected at less than $20 \mathrm{~m}$ depth. We therefore assume that the majority of the collected phytoplankton experienced total mixing at a time scale shorter than needed for photoacclimation to take place. In addition, all samples were prone to light-mediated movement in pigment protein complexes, known to affect $a^{*}{ }_{\mathrm{ph}}$ within short time scales (s to min; Kiefer 1973). Absence of

Table 4. Factorial ANOVA showing the effect of sampling region (Sea), sampling season (Season) and sampling depth (Depth) on mean spectral (400 to $700 \mathrm{~nm}$ ) chl a-specific absorption $\left(\hat{a}^{*}{ }^{*}\right)$. Significant factors are in bold. $n d=$ not done $(\mathrm{n}=244)$

\begin{tabular}{|lcccc|}
\hline $\begin{array}{l}\text { Source of } \\
\text { variation }\end{array}$ & df & $\begin{array}{c}\text { Type III } \\
\text { SS }\end{array}$ & Fvalue & $\mathrm{p}$ \\
\hline Sea & & 0.0029 & 18.72 & $\mathbf{< 0 . 0 0 0 1}$ \\
Season & 3 & 0.0004 & 1.69 & 0.169 \\
Depth & 1 & 0.0001 & 0.99 & 0.322 \\
Sea $\times$ Season & 1 & 0.0003 & 11.89 & $\mathbf{0 . 0 0 0 7}$ \\
Sea $\times$ Depth & 1 & 0.0002 & 3.00 & 0.085 \\
Season $\times$ Depth & 2 & 0.0003 & 1.82 & 0.164 \\
Sea $\times$ Season $\times$ Depth & 0 & 0 & nd & nd \\
\hline
\end{tabular}

any relationship between irradiance level and $\hat{a}^{*}{ }_{\mathrm{ph}}$ is therefore not surprising, considering the uncertainties with respect to mixing regime and time scale of adaptation.

Despite the overall differences in inorganic nutrient levels between the 3 water types (see Fig. 2), we only found very weak correlations with $\hat{a}^{*}{ }_{\mathrm{ph}}$. Assimilation of inorganic nutrients by phytoplankton may result in low ambient nutrient concentrations. This seems especially relevant for several of the coastal and estuarine samples, which were collected in waters characterized by receiving a continuous nutrient supply from land and experiencing a high remineralisation of nutrients from the sediment (Hansen et al. 2000). It therefore seems likely that nutrients were sufficiently available for phytoplankton growth in estuaries and coastal waters, even when measurable concentrations in the water column were low. Therefore, we would expect $\hat{a}^{*}$ ph to be better correlated

Table 5. Factorial ANOVA showing the effect of 5 levels of irradiance $\left(E_{\text {mean }}\right), \mathrm{NO}_{2}+\mathrm{NO}_{3}(\mathrm{DIN})$ and temperature $(\mathrm{T})$ on mean spectral (400 to $700 \mathrm{~nm}) \mathrm{chl} a$-specific absorption $\left(\hat{a}^{*}{ }^{*}\right)$. Significant factors are in bold $(n=244)$

\begin{tabular}{|lcccc|}
\hline $\begin{array}{l}\text { Source of } \\
\text { variation }\end{array}$ & df & $\begin{array}{c}\text { Type III } \\
\text { SS }\end{array}$ & $F$ value & $\mathrm{p}$ \\
\hline$E_{\text {mean }}$ & 4 & 0.0003 & 1.33 & 0.259 \\
$\mathrm{DIN}$ & 4 & 0.0005 & 1.82 & 0.125 \\
$\mathrm{~T}$ & 4 & 0.0008 & 3.29 & $\mathbf{0 . 0 1 2}$ \\
$E_{\text {mean }} \times \mathrm{DIN}$ & 8 & 0.0002 & 0.41 & 0.916 \\
$E_{\text {mean }} \times \mathrm{T}$ & 11 & 0.0011 & 1.56 & 0.115 \\
$\mathrm{DIN} \times \mathrm{T}$ & 7 & 0.0011 & 2.52 & $\mathbf{0 . 0 1 7}$ \\
$E_{\text {mean }} \times \mathrm{DIN} \times \mathrm{T}$ & 1 & 0.0001 & 1.25 & 0.2648 \\
\hline
\end{tabular}




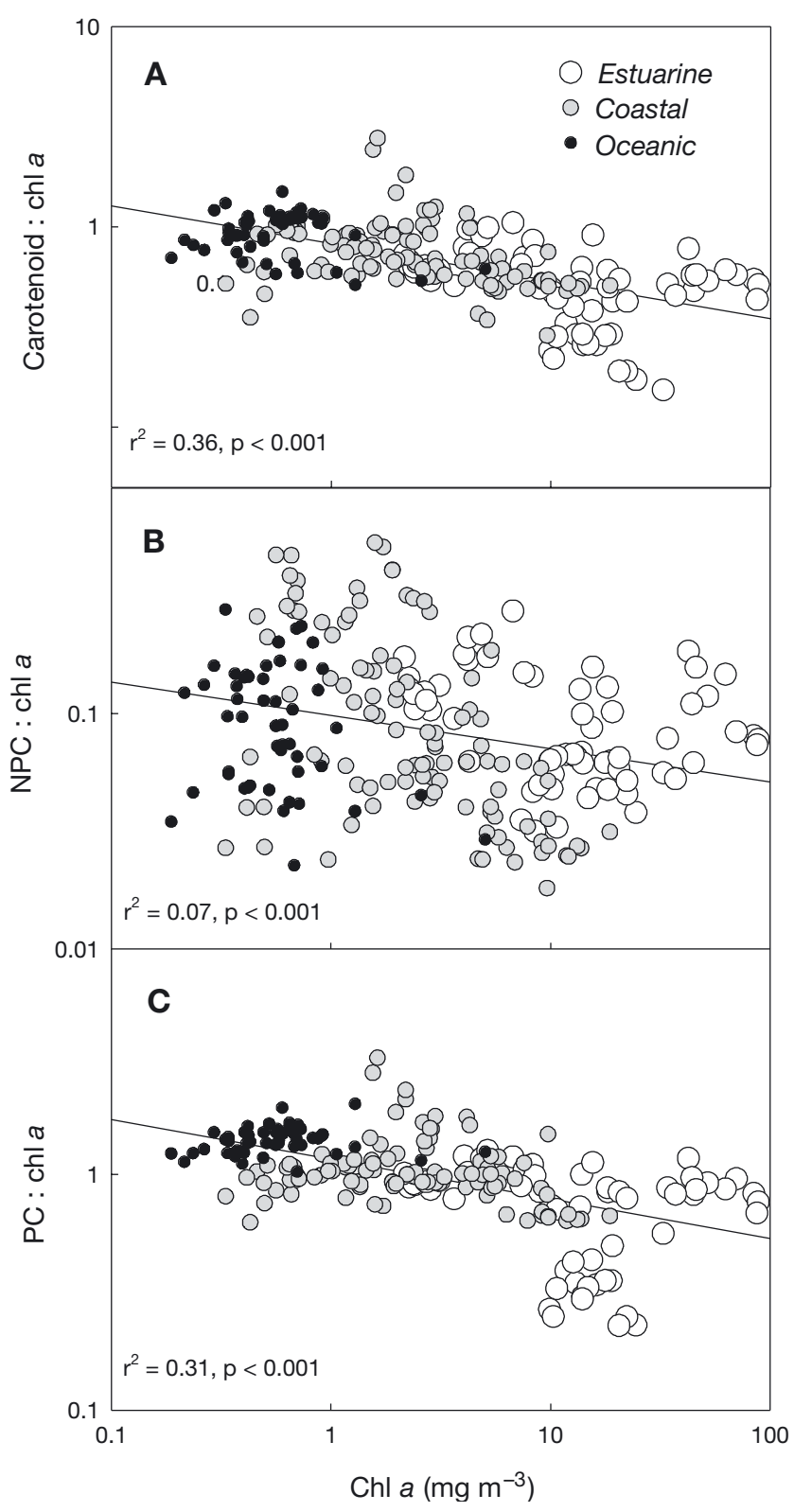

Fig. 9. (A)Variations of the ratio of carotenoids to $\mathrm{chl} a_{\text {, as a }}$ function of [chl a]. (B) Variations of the ratio of non-photosynthetic carotenoids (NPC) to chl a as a function of [chl a]. (C) Variations of the ratio of photosynthetic carotenoids (PC) to $\mathrm{chl} a$ as a function of [chl a]. Circle sizes indicate the differences in phytoplankton cell size seen in Fig. 2. Lines and $\mathrm{r}^{2}$ values were found by linear regression. $(n=220)$

with nutrient loading of the system than to the immediate concentration of dissolved nutrients.

In agreement with laboratory studies (Stramski et al. 2002), low growth temperatures were associated with higher $\hat{a}_{\mathrm{ph}}^{*}$ (Table 2). According to Stramski et al. (2002), acclimation to low temperature causes a significant increase in chl a-specific absorption through a

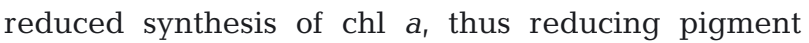
packaging. In contradiction to this, Bouman et al. (2003) found a positive relation between water temperature and the chl a-specific absorption coefficient when comparing samples collected over a wide range of oceanic regions. This was, according to their analysis, the result of a link between upwelling cold water and supply of new nitrogen to the surface favoring larger, more densely packed cells, rather than a direct effect of temperature on the photoacclimative state of the phytoplankton (Bouman et al. 2003). In a similar way, we do not believe that the significant increase in pigment packaging and thus $\hat{a}_{\mathrm{ph}}^{*}$, with increasing temperature, resulted from a direct effect on the photoacclimative state of the phytoplankton. Rather, the changes in $\hat{a}^{*}$ ph found across the oceanic to estuarine gradient, relate to changes in phytoplankton community structure caused by changes in nutrient availability and the water mixing regime favoring larger species.

The overall poor relationship between $\hat{a}^{*}$ ph and environmental conditions suggests that short-term cellular acclimation to the prevailing growth conditions is either insignificant or difficult to assess due to uncertainties in our measurements. Alternatively, short-term cellular acclimation may simply be less important than long-term adaptation of the phytoplankton community.

\section{Influence of phytoplankton community structure on $\hat{\boldsymbol{a}}_{\mathrm{ph}}^{*}$}

Phytoplankton composition differed significantly between the studied waters. Estimates of phytoplankton class abundance from pigments using the CHEMTAX software (Mackey et al. 1996) have become a valuable tool for analysing changes in phytoplankton composition (Jeffrey et al. 1999). However, the use of the CHEMTAX program requires some basic knowledge of the phytoplankton community and the growth conditions in a given area to obtain trustworthy results (Henriksen et al. 2002). In this study, CHEMTAX calculations of phytoplankton composition were performed on samples grouped according to similarities in growth conditions and a comprehensive knowledge of the species composition in the studied waters (Peter Henriksen pers. comm.). Furthermore, pigment ratio files, developed for phytoplankton species representative of the collected samples, were applied in the CHEMTAX computations to enhance the reliability of the class estimates. Although phytoplankton were counted under a microscope, it is unfortunately not possible to provide a reliable evaluation of the uncertainty of the CHEMTAX computations. Some of the samples were only counted with the purpose of obtain- 
ing cell numbers and cell dimensions. The rest of the counts suffer from the artefact that smaller sized taxa (especially within the prymnesiophytes and prasinophytes; Fig. 4) are difficult to identify using an inverted microscope and are, therefore, often classified as 'unidentified flagellates', which sometimes comprised $50 \%$ of the total biomass in the Greenland Sea samples. The problem of comparing CHEMTAX computed phytoplankton composition with direct counts (using the Utermöhl method) is dealt with in detail by Henriksen et al. (2002). They conclude that realistic estimates of phytoplankton community structure can be obtained using CHEMTAX as long as a thorough knowledge of the phytoplankton community of the given area is available, as in this study.

The CHEMTAX computations showed a pattern in phytoplankton community structure, suggesting that diatoms become more dominant with increasing algal biomass in estuaries and coastal waters. The presence of diatoms were also closely related to the availability of silica $\left(R_{S}=0.48, p<0.001\right)$, which had higher concentrations in estuarine and coastal waters (Fig. 2). Conversely, the smaller sized phytoplankton species dominated at low $[\mathrm{chl}$ a] in the oceanic waters (Figs. 2 \& 3). The changes in phytoplankton composition and size structure across the studied waters conform well to previous findings by Kiørboe (1993). According to Kiørboe, small phytoplankton cells are superior to large cells with respect to nutrient uptake and light harvesting ability in oligotrophic environments, whereas the large cells typical of coastal and estuarine waters are thought to have a greater storage capacity for nutrients and be better competitors under high and fluctuating nutrient regimes. In addition, the high abundance and long survival of living diatoms in the upper marine sediments of coastal waters suggest that diatoms located in the sediment may serve as a 'seed bank', inoculating the water column of shallow waters during periods of water mixing (Hansen \& Josefson 2001). Several conditions therefore seem to favour the dominance of diatoms in coastal and estuarine waters.

The gradual decrease in abundance of diatoms from estuarine to oceanic waters was associated with a significant change in optical properties. In agreement with previous studies, we found that phytoplankton communities dominated by diatoms had a high intracellular pigment concentration and low chl $a$-specific absorption coefficients (Stuart et al. 2000). Although a significant variability has been found in pigment packaging and $a^{*}{ }_{\mathrm{ph}}$ within diatoms (Finkel 2001), they generally consist of larger species (Fig. 4) causing the negative correlation between relative abundance of diatoms and $\hat{a}^{*}{ }_{\mathrm{ph}}\left(\mathrm{R}_{\mathrm{S}}=-0.39, \mathrm{p}<0.001\right)$ found in this study.

\section{Conclusions}

This study documents profound differences in the physico-chemical environment in estuarine, coastal and oceanic waters. These differences were also reflected in corresponding systematic changes in phytoplankton community structure, pigmentation and the chl $a$-specific absorption coefficient $\left(a^{*}{ }_{\mathrm{ph}}\right)$. A gradual flattening of the $a^{*}$ ph spectra from oceanic, over coastal, to estuarine waters was observed. This change coincided with a greater cell size and greater relative abundance of diatoms in the phytoplankton community and in higher pigment packaging and a lower carotenoid : chl a ratio. No clear relation was found between $a^{*}$ ph and light, temperature, salinity or nutrient availability, indicating that optical acclimation of the phytoplankton to the prevailing environmental conditions was of minor importance for the observed differences in $a_{\mathrm{ph}}^{*}$ between estuarine, coastal and oceanic waters. Rather, this study provides strong evidence that the variability in $a^{*}$ ph was caused by a longer-term adaptation of the phytoplankton community. Our data suggests that an overall increase in nutrient loading from oceanic to estuarine waters increases phytoplankton abundance and favors larger size species, particularly within the diatoms. These changes eventually decrease $a^{*}$ ph through a rise in intracellular pigment concentration and a lower abundance of carotenoids relative to chl $a$.

Acknowledgements. This paper was prepared as a part of the DECO (Danish Environmental monitoring of COastal waters) project. The DECO project was financed by the Danish Earth Observation Program grant no. 9600667. Further funding was provided by the Danish Natural Science Research Council, Global Change Program grant no. 9700196. W. Martinsen and C. Stedmon both participated in various parts of the field and laboratory work, for which we are grateful. We greatly appreciate P. Henriksen for performing CHEMTAX calculations and providing information on the HPLC analysis. The possibility to use data from the Danish national monitoring program is also appreciated.

\section{LITERATURE CITED}

Allali K, Bricaud A, Claustre H (1997) Spatial variations in the chlorophyll-specific absorption coefficients of phytoplankton and photosynthetically active pigments in the equatorial Pacific. J Geophys Res 102:12413-12423

Arbones B, Figueiras FG, Zapata (1996) Determination of phytoplankton absorption coefficient in natural seawater samples: evidence of a unique equation to correct the pathlength amplification on glass-fiber filters. Mar Ecol Prog Ser 137:293-304

Berner T, Dubinsky Z (1989) Photoadaption and the 'package' effect in Dunaliella tertiolecta (Chlorophyceae). J Phycol 25:70-78

Bodungen B, Antia A, Bauerfeind E, Haupt $O$ and 10 others (1995) Pelagic processes and vertical flux of particles. An 
overview of a long-term comparative study in the Norwegian Sea and Greenland Sea. Geol Rund 84:11-27

Bouman HA, Platt T, Sathyendranath S, Li WKW and 7 others (2003) Temperature as indicator of optical properties and community structure of marine phytoplankton: implications for remote sensing. Mar Ecol Prog Ser. 258:19-30

Bricaud A, Stramski D (1990) Spectral absorption coefficients of living phytoplankton and nonalgal biogenous matter: A comparison between the Peru upwelling area and the Sargasso Sea. Limnol Oceanogr 35:562-582

Bricaud A, Babin M, Morel A, Claustre H (1995) Variability in the chlorophyll-specific absorption coefficients of natural phytoplankton: Analysis and parameterisation: J Geophys Res 100:13321-13332

Bricaud A, Bédhomme AL, Morel A (1988) Optical properties of diverse phytoplankton species: experimental results and theoretical interpretation. J Plankton Res 10:851-873

Bricaud A, Morel A, Prieur L (1983) Optical efficiency factors of some phytoplankters. Limnol Oceanogr 28:816-832

Chalup MS, Laws EA (1990) A test of the assumptions and predictions of recent microalgal growth models with the marine phytoplankter Pavlova lutheri. Limnol Oceanogr 35:583-596

Ciotti AM, Cullen JJ, Lewis MR (1999) A semi-analytical model of the influence of phytoplankton community structure on the relationship between light attenuation and ocean color. J Geophys Res 104:1559-1578

Ciotti AM, Lewis MR, Cullen JJ (2002) Assessment of the relationship between dominant cell size in natural phytoplankton communities and the spectral shape of the absorption coefficient. Limnol Oceanogr 47(2):404-417

Clarke KR (1993) Non-parametric multivariate analysis of changes in community structure. Aust J Ecol 18:117-143

Clarke KR, Warwick RM (1994) Change in marine communities: an approach to statistical analysis and interpretation. Bourne Press Limited, Bournemouth

Cleveland JS (1995) Regional models for phytoplankton absorption as a function of chlorophyll a concentration. J Geophys Res 100:13333-13344

Falkowski PG, LaRoche J (1991) Acclimation to spectral irradiance in algae. J Phycol 27:8-14

Falkowski PG, Raven JA (1997) Aquatic photosynthesis. Blackwell Science, Massachusetts

Finkel ZV (2001) Light absorption and size scaling of lightlimited metabolism in marine diatoms. Limnol Oceanogr 46(1):86-94

Finkel ZV, Irwin AJ (2001) Light absorption by phytoplankton and the filter amplification correction: cell size and species effects. J Exp Mar Biol Ecol 259:51-61

Fowler J, Cohen L (1990) Practical statistics for field biology. John Wiley \& Sons, New York

Fujiki T, Taguchi S (2002) Variability in chlorophyll a specific absorption coefficient in marine phytoplankton as a function of cell size and irradiance. J Plankton Res 24(9): 859-874

Gordon HR, Morel A (1983) Remote assessment of ocean color for interpretation of satellite visible imagery. A review. In Barber RT, Mooers NK, Bowman MJ, Zeitzschel B (eds) Lecture notes on coastal and estuarine studies. SpringerVerlag, New York

Hansen JLS, Josefson AB (2001) Pools of chlorophyll and live diatoms in aphotic marine sediments. Mar Biol 139:289-299

Hansen JLS, Pedersen B, Carstensen J, Conley D and 19 others (2000) Marine områder - Status over miljøtilstanden i 1999. National Environmental Research Institute of Denmark Tech Rep 333 (In Danish)

Henriksen P, Riemann B, Kaas H, Sørensen HM, Sørensen
HL (2002) Effects of nutrient-limitation and irradiance on marine phytoplankton pigments. J Plankton Res 24(9): $835-858$

Herzig R, Falkowski PG (1989) Nitrogen limitation in Isochrysis galbana (Haptophyceae). I. Phytosynthetic energy conversion and growth efficiencies: J Phycol 25:462-471

Hillebrand $H$, Dürselen C-D, Kirschtel D, Pollingher U, Zohary $\mathrm{T}$ (1999) Biovolume calculation for pelagic and benthic microalgae. J Phycol 35:403-424

Hoepffner N, Sathyendranath S (1991) Effect of pigment composition on absorption properties of phytoplankton. Mar Ecol Prog Ser 73:11-23

Hoepffner N, Sathyendranath S (1992) Bio-optical characteristics of coastal waters: Absorption spectra of phytoplankton and pigment distribution in the western North Atlantic. Limnol Oceanogr 37:1660-1679

Højerslev NK (1977) Spectral daylight irradiance and light transmittance in natural waters measured by means of a Secchi disc only. International Council for the Exploration of the Sea. Code No. C.M. 1977 / C:42, Hydrography Committee

Jeffrey SW, Hallegraeff GM (1987) Chlorophyllase distribution in ten classes of phytoplankton: a problem for chlorophyll analysis. Mar Ecol Prog Ser 35:293-304

Jeffrey SW, Wright SW, Zapata M (1999) Recent advances in HPLC pigment analysis of phytoplankton. Mar Freshw Res 50:879-896

Jensen SE (2000) Agroclimate at Taastrup 2000. Agrohydrology and Bioclimatology. Department of Agricultural Science. Royal Vet. And Agric. University of Copenghagen.

Johnsen G, Prézelin BB, Jovine RVM (1997) Fluorescence excitation spectra and light utilization in two red tide dinoflagellates. Limnol Oceanogr 42(5):1166-1177

Kaas H, Markager S (1998) Teknisk anvisning for marin overvågning. (In Danish). National Environmental Research Institute of Denmark, Roskilde

Kiefer DA (1973) Chlorophyll a fluorescence in marine centric diatoms: responses of chloroplasts to light and nutrient stress. Mar Biol 23:39-46

Kiørboe T (1993) Turbulence, phytoplankton cell size, and the structure of pelagic food webs. Adv Mar Biol 29:1-62

Kishino M, Takahashi M, Okami N, Ichimura S (1985) Estimation of the spectral absorption coefficients of phytoplankton in the sea. Bull Mar Sci 37:634-642

Lutz VA, Sathyendranath S, Head EJH (1996) Absorption coefficient of phytoplankton: regional variations in the North Atlantic. Limnol Oceanogr 135:197-213

Mackey MD, Mackey DJ, Higgins HW, Wright SW (1996) CHEMTAX - a program for estimating class abundances from chemical markers: application to HPLC measurements of phytoplankton. Mar Ecol Prog Ser 144:265-283

Markager S, Vincent WF (2001) Light absorption by phytoplankton: development of a matching parameter for algal photosynthesis under different spectral regimes. J Plankton Res 23(12):1373-1384

Menden-Deuer S, Lessard EJ, Satterberg J (2001) Effect of preservation on dinoflagellate and diatom cell volume and consequences for carbon biomass predictions. Mar Ecol Prog Ser 222:41-50

Mitchell BG, Kiefer DA (1988) Chlorophyll a specific absorption and fluorescence excitation spectra for light-limited phytoplankton. Deep-Sea Res 35(5):639-663

Moore LR, Goericke R, Chisholm SW (1995) Comparative physiology of Synechococcus and Prochlorococcus: influence of light and temperature on growth, pigments, flourescence and absorptive properties. Mar Ecol Prog Ser 116:259-275 
Morel A, André JM (1991) Pigment distribution and primary production in the western Mediterranean as derived and modeled form Coastal Zone Color Scanner observations. J Geophys Res 96:12685-12698

Morel A, Bricaud A (1981) Theoretical results concerning light absorption in a discrete medium, and application to specific absorption of phytoplankton: Deep-Sea Res 28 Part A Oceanogr Res Pap 1375-1393

Ohi N, Ishiwata Y, Taguchi S (2002) Diel patterns in light absorption and absorption efficiency factors of Isochrysis galabana (Prymnesiophyceae): J Phycol 38:730-737

Platt T, Sathyendranath S (1988) Oceanic primary production: Estimation by remote sensing at local and regional scales. Science 241:1613-1620

Platt T, Sathyendranath S, Longhurst A (1995) Remote sensing of primary production in the ocean: Promise and fulfilment. Philos Trans R Soc Lond, Ser B 348:191-202

Rasmussen B, Gustafsson BG (2003) Computation of nutrient pools and fluxes at the entrance to the Baltic Sea, 1974-1999. Cont Shelf Res 23 (5):483-500

Riley GA (1957) Phytoplankton of the North Central Sargasso Sea, 1950-1952. Limnol Oceanogr 2:252-270

SAS Institute Inc. (1994) SAS/STAT Users Guide, Vol. 2, Version 6, 4th ed. SAS Institute, Cang, NC

Sathyendranath S, Lazzara L, Prieur L (1987) Variations in the spectral values of specific absorption of phytoplankton. Limnol Oceanogr 32:403-415

Sathyendranath S, Longhurst A, Caverhill CM, Platt T (1995) Regionally and seasonally differentiated primary production in the North Atlantic. Deep-Sea Res I 43:1773-1802

Sathyendranath S, Stuart V, Irwin BD, Maass H, Savidge G, Gilpin L, Platt T (1999) Seasonal variations in bio-optical properties of phytoplankton in the Arabian Sea. Deep-Sea Res II 46:633-653

Schlüter L, Havskum H (1997) Phytoplankton pigments in

Editorial responsibility: Otto Kinne (Editor),

Oldendorf/Luhe, Germany relation to carbon content in phytoplankton communities. Mar Ecol Prog Ser 155:55-65

Sosik HM, Mitchell BG (1991) Absorption, fluorescence, and quantum yield for growth in nitrogen-limited Dunaliella tertiolecta. Limnol Oceanogr 36:910-921

Sosik HM, Mitchell BG (1995) Light absorption by phytoplankton, photosynthetic pigments and detritus in the California current system. Deep-Sea Res I 42:1717-1748

Stæhr PA, Cullen JJ (2003) Detection of Karenia mikimotoi by spectral absorption signatures. J Plankton Res 25(10): 1237-1249

Stæhr PA, Henriksen P, Markager S (2002) Photoacclimation of four marine phytoplankton species to irradiance and nutrient availability. Mar Ecol Prog Ser 238:47-59

Stramski D, Sciandra A, Claustre H (2002) Effects of temperature, nitrogen, and light limitation on the optical properties of the marine diatom Thalassiosira pseudonana. Limnol Oceanogr 47(2):392-403

Stuart V, Sathyendranath S, Platt T, Maass H, Irwin BD (1998) Pigments and species composition of natural phytoplankton populations: effect on the absorption spectra. J Plankton Res 20:187-217

Stuart V, Sathyendranath S, Head EJH, Platt T, Irwin B, Mass $\mathrm{H}$ (2000) Bio-optical characteristics of diatom and prymnesiophyte populations in the Labrador Sea. Mar Ecol Prog Ser 201:91-106

Trees CC, Clark DK, Bidigare RR, Ondrusek ME, Mueller JL (2000) Accessory pigments versus chlorophyll a concentrations with in the euphotic zone: A ubiquitous relationship. Limnol Oceanogr 45(5):1130-1143

Wright SW, Jeffrey SW, Mantoura RFC, Llewellyn CA, Bjørnland T, Repeta D, Welschmeyer N (1991) Improved HPLC method for the analysis of chlorophylls and carotenoids from marine phytoplankton. Mar Ecol Prog Ser 77: $285-298$

Submitted: May 24, 2002; Accepted: March 9, 2004

Proofs received from author(s): June 23, 2004 